\title{
IDENTIFIKASI MUTU FISIK KIMIA DAN ORGANOLEPTIK PENAMBAHAN EKSTRAK JAHE (Zingiber officinale) PADA PEMBUATAN ES KRIM SARI KACANG HIJAU (Phaseolus radiatus L.)
}

\{Identification physical, chemistry, and sensories qualities Of Addition Of Ginger Extract (Zingiber officinale) In The Making Of Ice Cream Mung Bean Extract (Phaseolus radiatus L.)\}

\author{
Muhammad Iqbal Nusa, Masyhura MD and Fitra Abdul Hakim \\ Teknologi Hasil Pertanian \\ Fakultas Pertanian Universitas Muhammadiyah Sumatera Utara
}

\begin{abstract}
The hight sensories taste of Ginger extract can used as adding taste material potentially. The Ice cream is most popularity foods as semi-solid food made by freezing a mixture of ice cream material. This study was conducted to determine the effect of adding ginger extract (Zingiber officinale) to the manufacture of green bean juice ice cream (Phaseolus radiatus L.). This study uses a completely randomized factorial design method with two factors, namely factor I: the proporsion adding of the number ginger extract and mung bean extract $(\mathrm{J}, \mathrm{v} / \mathrm{v})$ at 4 levels, namely $\mathrm{J} 1=10: 90$, $\mathrm{J} 2=20: 80, \mathrm{~J} 3=30: 70, \mathrm{~J} 4=40: 60$, factor II: the concentration of full cream milk $(\mathrm{S}, \mathrm{w} / \mathrm{v})$ at 4 levels namely S1 $=5 \%, \mathrm{~S} 2=10 \%, \mathrm{~S} 3=15 \%, \mathrm{~S} 4=20 \%$. The parameters observed were protein content, overrun, melting time and flavor organoleptic. The proportion of the addition of ginger extract to green bean juice ice cream has a very significant different effect on protein content, overrun, melting time and organoleptic taste. The concentration of full cream milk has a very significant effect on protein content, overrun, melting time and organoleptic taste
\end{abstract}

Keywords: Ice Cream, Ginger, Mung Beans, full cream Milk.

\section{A. PENDAHULUAN}

Es krim salah satu makanan yang popular dan merupakan makanan semi padat yang dibuat dengan cara pembekuan campuran susu yang biasa dikonsumsi sebagai makanan selingan (desert) . Prinsip pembuatan es krim adalah membentuk rongga udara pada campuran bahan es krim sehingga diperoleh pengembangan volume yang membuat es krim menjadi lebih ringan, tidak terlalu padat, dan mempunyai tekstur yang lembut (Padaga dan Sawitri, 2005).

Saat ini di Indonesia, es krim yang memiliki varian rasa yaitu vanilla, cokelat dan strawberi. Umumnya es krim terbuat dari campuran buah-buahan dan untuk campuran rempah-rempah serta biji-bijian masih jarang digunakan contohnya pada Jahe dan kacang hijau yang kaya akan manfaat bagi kesehatan tubuh.

$\begin{array}{llll} & \text { Jahe (Zingiber officinale) merupakan } \\ \text { tanaman rempah yang umumnya }\end{array}$ dimanfaatkan sebagai minuman atau campuran pada bahan pangan. Rasa jahe yang pedas bila diolah memberi sensasi sebagai pelegah dan penyegar tenggorokan. Jahe memiliki kandungan minyakatsiri zingiberena (zingirona), zingiberol, bisabolena, kurkumen, gingerol, filandrena, dan resin yang baik untuk kesehatan tubuh seperti mengatasi masalah pencernaan, mencegah tersumbatnya pembuluh darah, mencegah mual, menetralkan radikal bebas. Sejak lama jahe dimanfaatkan sebagai bumbu dapur dan obat tradisional. Misalnya jahe digunakan dalam masakan karena dapat menghilangkan bau amis. Jahe segar dapat digunakan langsung sebagai obat. Irisan jahe juga dapat digunakan untuk melapangkan tenggorokan. Penyajian lainnya dapat dikonsumsi dengan disedu atau dibuat minuman. Jahe memliki khasiat menghalau serangan angin, mengaktifkan sirkulasi darah dalam tubuh, mengurangi rasa sakit pada wanita yang mengalami menstruasi dan menghangatkan tubuh. Jahe memiliki kandungan gizi yang cukup lengkap, baik bagi kesehatan, memiliki rasa yang khas serta masih kurang dan terbatasnya olahan produk jahe, oleh karena itu jahe akan diolah menjadi sebuah produk, salah satunya es krim (Budi, 2009).

Untuk penambahan varian cita rasa es krim yang dihasilkan, dilakukan penambahan bahan pembuatan es krim dengan buah-buahan, kacang-kacangan, ataupun rempah-rempah. Kacang hijau sumber gizi, terutama protein nabati. Kacang hijau memiliki kandungan protein yang cukup tinggi dan merupakan sumber mineral penting, antara lain kalsium dan fosfor. Kandungan kalsium dan fosfor pada kacang 
hijau bermanfaat untuk memperkuat tulang. Kacang hijau juga mengandung rendah lemak yang sangat baik, kadar lemak yang rendah dalam kacang hijau menjadikan bahan makanan atau minuman yang terbuat dari kacang hijau tidak mudah berbau. Lemak kacang hijau tersusun atas $73 \%$ asam lemak tak jenuh dan $27 \%$ asam lemak jenuh. Umumnya kacang-kacangan memang mengandung lemak tak jenuh tinggi. Asupan lemak tak jenuh tinggi penting untuk menjaga kesehatan jantung. Mengkonsumsi kacang hijau secara teratur dapat menurunkan kadar kolesterol jahat (Amrina, 2013).

\section{B. METODE PENELITIAN Bahan dan Alat}

Bahan yang digunakan meliputi: jahe, kacang hijau, susu full cream, whipping cream, gula pasir, gum arab, air dan kuning telur.

Adapun alat penelitian yang digunakan dalam penelitian adalah sebagai berikut: Mixer, kompor, freezer, pisau, wadah, pengaduk, sendok, blender, mesin pembuat es krim, beaker glass, timbangan analitik, saringan, panci, tabung reaksi, tabung kjeldahl, pemanas kjeldahl, erlenmeyer, spektrofometer visible, pipet tetes, pipet tetes, plastik cap

\section{Rancangan Penelitian}

Penelitian menggunakan Rancangan Acak Lengkap (RAL) Faktorial yang terdiri dari dua faktor yaitu: Faktor I : Proporsi Penambahan Ekstrak Jahe Pada Es Krim Sari Kacang Hijau (J) terdiri dari 4 taraf yaitu : J1 $=10: 90, \mathrm{~J} 2=20: 80, \mathrm{~J} 3=30: 70, \mathrm{~J} 4=40:$ 60, Faktor II : Penambahan konsentrasi Susu full cream (S) yang terdiri dari 4 taraf yaitu : $\mathrm{S} 1=5 \%, \mathrm{~S} 2=10 \%, \mathrm{~S} 3=15 \%, \mathrm{~S} 4=20 \%$.

\section{Pembuatan Ekstrak Jahe}

Bersihkan jahe dari sisa sisa tanah yang menempel dan kulit jahe yang hitam dan kotor di bersihkan dengan menggunakan pisau hingga cukup bersih. Jahe dipotong menjadi bagian-bagian yang kecil untuk memudahkan penghancuran dengan pembelenderan. Blender sampai halus dengan menambahkan perbandingan air 1:4, lakukan pemisahan cairan ekstrak dari ampas dengan penyaringan dan pengendapan.

\section{Pembuatan bubur Sari Kacang Hijau}

Bersihkan kacang hijau dari kotoran, seperti batu-batu kecil, puing-puing dari polong, atau kotoran lainnya. Rendam kacang hijau selama \pm 12 jam, tujuannya untuk melunakkan biji kacang hijau sehingga meringkas waktu memasaknya. Setelah proses perendaman selesai, selanjunya buang air hasil rendaman nya dan blender dengan perbandingan air 1:4. Siapkan panci, masukkan kacang hijau yang telah di blender ke dalam panci tersebut, rebus dengan api kecil \pm 20 minit, sesekali air rebusan diaduk. kemudian angkat panci, dinginkan dan ambil sari kacang hijaunya.

\section{Pembuatan Es Krim Ekstrak Jahe dan Sari Kacang Hijau}

Ekstrak jahe dan sari kacang hijau yang telah di saring, lakukan pencampuran antara ekstrak jahe dan sari kacang hijau sesuai dengan proporsi berikut (10:90, 20:80, 30:70, 40:60), tambahkan susu full cream (5\%, 10\%, 15\%, 20\%), whipping cream $10 \%(\mathrm{~b} / \mathrm{b})$, gula $20 \%(\mathrm{~b} / \mathrm{b})$, gum arab $0.25 \%$ (b/b), dan tambahkan kuning telur. Campurkan semua bahan didalam mixer selama 5-6 menit. Kemudian masukkan adonan yang telah di mixer kedalam mesin pembuat es krim (soft ice cream). Tunggu kurang lebih selama 15-20 menit atau sampai mesin mati. Masukkan es krim kedalam wadah atau tempat yang disediakan. Kemudian simpan di dalam freezer dan dilakukan pengamatan terhadap kadar protein, pengukuran kualitas (overrun), waktu leleh, dan organoleptik rasa

\section{HASIL DAN PEMBAHASAN}

Hasil pengamatan parameter menunjukkan bahwa proporsi penambahan ekstrak jahe pada es krim sari kacang hijau berpengaruh terhadap parameter yang diamati. Rerata hasil pengamatan proporsi penambahan ekstrak jahe pada es krim sari kacang hijau terhadap masing-masing parameter dapat dilihat pada table berikut

Tabel 1. Pengaruh Proporsi penambahan ekstrak jahe pada es krim sari kacang hijau berpengaruh terhadap parameter yang diamati

\begin{tabular}{|l|c|c|c|c|}
\hline $\begin{array}{c}\text { Proporsi } \\
\text { Penambahan } \\
\text { Ekstrak } \\
\text { Jahe }(\mathrm{J})(\%)\end{array}$ & $\begin{array}{c}\text { Kadar } \\
\text { Protein } \\
(\%)\end{array}$ & $\begin{array}{c}\text { Pengukuran } \\
\text { Kualitas } \\
\text { (Overrun) } \\
(\%)\end{array}$ & $\begin{array}{c}\text { waktu } \\
\text { Leleh } \\
(\text { Menit) }\end{array}$ & $\begin{array}{c}\text { Organoleptik } \\
\text { Rasa }\end{array}$ \\
\hline $\mathrm{J} 1=10: 90$ & $5,31 \mathrm{a}$ & $27,61 \mathrm{a}$ & $3,26 \mathrm{a}$ & $3,40 \mathrm{a}$ \\
\hline $\mathrm{J} 2=20: 80$ & $4,50 \mathrm{a}$ & $31,27 \mathrm{~b}$ & $2,89 \mathrm{ab}$ & $3,15 \mathrm{a}$ \\
\hline $\mathrm{J} 3=30: 70$ & $4,03 \mathrm{a}$ & $34,28 \mathrm{C}$ & $2,76 \mathrm{~b}$ & $2,69 \mathrm{~b}$ \\
\hline $\mathrm{J} 4=40: 60$ & $3,52 \mathrm{a}$ & $39,51 \mathrm{~d}$ & $2,43 \mathrm{~b}$ & $2,46 \mathrm{~b}$ \\
\hline
\end{tabular}

Keterangan : Angka yang diikuti oleh kode huruf yang berbeda menunjukkan adanya perbedaa yang nyata pada taraf signifikansi $5 \%$ 
Pada tabel 1 diatas menunjukkan bahwa semakin tinggi penambahan proporsi ekstrak jahe terhadap sari kacang hijau, maka kadar protein, waktu leleh dan organoleptik rasa akan manurun, sedangkan pengukuran kualitas (overrun) meningkat.

\section{Kandungan Protein (\%)}

Proporsi penambahan ekstrak sari jahe tidak berpengaruh nyata terhadap kadar protein es krim sari kacang hijau. Pada pembuatan es krim ekstrak jahe dan sari kacang hijau, kandungan protein berasal dari biji kacang hijau,susu skim dan telur. Kacang hijau merupakan sumber protein nabati, sehingga pada perlakuan proporsi penambahan sari terendah yaitu pada perlakuan J1 kadar protein yang paling tinggi. Karena pada perlakuan ini proporsi sari kacang hijau dalam bahan adalah yang tertinggi di bandingkan perlakuan yang lain. Semakin sedikit proporsi sari kacang hijau di dalam bahan pembuatan es krim maka kadar protein es krim yang dihasilkan akan semakin rendah.

\section{Over run $(\%)$}

Proporsi penambahan ekstrak sari jahe es krim sari kacang hijau terhadap pengukuran overrun berpengaruh nyata.

Secara kuntitatif penambahan ekstrak jahe akan meningkatkan overrun es krim. Overrun merupakan pengembangan volume yaitu kenaikan volume antara sebelum dan sesudah proses pembekuan. Overrun merupakan salah satu faktor yang mempengaruhi struktur es krim yang berhubungan dengan volume pengembangan es krim (Hubeis, 1995). Tingginya fraksi padatan pada bahan es krim dapat mempengaruhi nilai overrun disebabkan kemampuan untuk membentuk rongga udara pada adonan yang dapat memerangkap udara menjadi rendah. Sesuai yang dikemukakan oleh Muse dan Hartel (2004) bahwa adonan yang kental dari bahan pembuatan es krim akan menyebabkan overrun rendah karena adonan mengalami kesulitan untuk mengembang dan udara sulit menembus masuk permukaan adonan.

\section{Waktu Leleh (menit)}

Proporsi penambahan ekstrak sari jahe es krim sari kacang hijau berpengaruh nyata terhadap waktu meleleh es krim. Secara kuatitatif penambahan ekstrak sari jahe akan mempercepat waktu meleleh es krim. Kecepatan meleleh adalah waktu yang dibutuhkan es krim untuk meleleh sempurna pada suhu ruang setelah pembekuan dalam freezer. Es krim diharapkan tidak cepat meleleh pada suhu ruang namun cepat meleleh pada suhu tubuh (Hubeis, 1995). Padaga et al., (2005) menyatakan bahwa lemak susu berfungsi untuk menghasilkan karakteristik tekstur yang lembut, membantu memberikan bentuk dan kepadatan serta memeberikan sifat meleleh yang baik. Penambahan proporsi ekstrak sari jahe dalam bahan es krim akan menurunkan fraksi kandungan lemak dalam bahan, sehingga mempercepat waktu meleleh dari es krim sari kacang hijau.

\section{Organoleptik Rasa}

Rasa merupakan sensasi yang terbentuk dari hasil perpaduan bahan dan komposisinya pada suatu produk makanan oleh indra pengecap. Suatu produk dapat diterima oleh konsumen apabila memiliki rasa yang sesuai dengan yang diinginkan (Kartika, dkk, 1988). Proporsi penambahan ekstrak sari jahe es krim sari kacang hijau berpengaruh nyata terhadap organolepstik rasa. Rasa pedas jahe pada es krim sari kacang hijau kurang disukai oleh panelis. Pada proporsi penambahan ekstrak jahe pada perlakuan J1 adalah es krim sari kacang hijau yang paling disukai. Sedangkan perlakuan J4 adalah rasa es krim sari kacang hijau yang paling kurang disukai panelis. Ekstraksi jahe lebih mendominasi dari pada kacang hijau, sehingga rasa yang di ciptakan menjadi lebih pedas. Zat penyusun utama yang terdapat didalam jahe yaitu minyak jahe dan oleoresin. Minyak atsiri memberikan aroma harum sedangkan oleoresin memberikan rasa pedas. Oleoresin jahe banyak mengandung komponen pembentuk rasa pedas yang terdiri atas gingerol,

zingiberen, shagaol, minyak jahe dan resin. Penambahan ekstrak jahe dapat mengurangi aroma amis dari susu maupun dari kacang hijau pada es krim sari kacang hijau, (Setyawan, 2015)

Penambahan prosentase susu skim pada es krim sari kacang hijau berpengaruh terhadap parameter yang diamati. Nilai rerata hasil pengamatan penambahan prosentase susu skim pada es krim sari kacang hijau terhadap masing-masing parameter dapat dilihat pada tabel berikut 
Tabel 2. Pengaruh penambahan konsentrasi susu skim

\begin{tabular}{|c|c|c|c|c|}
\hline $\begin{array}{l}\text { Konsentrasi } \\
\text { Susu } \\
\text { Full Cream } \\
\text { (S) (\%) }\end{array}$ & $\begin{array}{c}\text { Kadar } \\
\text { Protein } \\
\text { (\%) }\end{array}$ & $\begin{array}{c}\text { Pengukuraa } \\
\text { Kualitas } \\
\text { (Overrun) } \\
(\%)\end{array}$ & $\begin{array}{c}\text { Waktu } \\
\text { Leleh } \\
\text { (Menit) }\end{array}$ & $\begin{array}{c}\text { Organoleptik } \\
\text { Rasa }\end{array}$ \\
\hline$s 1=5$ & $4.16 \mathrm{a}$ & 31.62 a & $2.98 \mathrm{a}$ & $2,74 \mathrm{a}$ \\
\hline$s 2=10$ & $4.31 \mathrm{a}$ & $32.92 \mathrm{a}$ & $2.85 \mathrm{a}$ & $2.80 \mathrm{a}$ \\
\hline$S 3=15$ & $4,38 \mathrm{ab}$ & $33,38 \mathrm{ab}$ & $2.80 \mathrm{ab}$ & $2,98 \mathrm{ab}$ \\
\hline$\$ 4=20$ & $4.51 \mathrm{~b}$ & $34.76 \mathrm{~b}$ & $2.72 \mathrm{~b}$ & $3.19 \mathrm{~b}$ \\
\hline
\end{tabular}

Keterangan : Angka yang diikuti oleh kode huruf yang berbeda menunjukkan adanya perbedaan yang nyata pada taraf signifikan $5 \%$

\section{Kandungan Protein (\%)}

Penambahan prosentase susu full cream berpengaruh nyata terhadap kadar protein es krim sari kacang hijau. Pada pembuatan es krim ekstrak jahe dan sari kacang hijau, kandungan protein berasal dari biji kacang hijau,susu skim dan telur. Pada perlakuan penambahan susu skim tertinggi yaitu pada perlakuan $\mathrm{S}_{4}$ kadar protein yang paling tinggi. Karena pada perlakuan ini komposisi bahan pembuatan es sari kacang hijau dalam bahan adalah sumber bahan yang mengandung protein. Sehingga kandungan protein es krim yang dihasilkan akan semakin tinggi.

\section{Overrun (\%)}

Penambahan prosentase susu full cream pada pembuatan es krim sari kacang hijau terhadap pengukuran overrun berpengaruh nyata. Overrun merupakan pengembangan volume yaitu kenaikan volume antara sebelum dan sesudah proses pembekuan. Overrun merupakan salah satu faktor yang mempengaruhi struktur es krim yang berhubungan dengan volume pengembangan es krim (Hubeis, 1995). Fraksi padatan pada bahan es krim dapat mempengaruhi nilai overrun disebabkan kemampuan untuk membentuk rongga udara pada adonan yang dapat memerangkap udara menjadi rendah. Sesuai yang dikemukakan oleh Muse dan Hartel (2004) bahwa adonan yang kental dari bahan pembuatan es krim akan menyebabkan overrun rendah. Penambahan susu yang mengandung cream akan mempermudah adonan bahan untuk mengembang sehingga udara berdifusi kedalam pada proses pencampuran pada proses pembuatan es krim sari kacang hijau.

\section{Waktu Leleh (menit)}

Penambahan prosentase susu kream pada pembuatan es krim sari kacang hijau berpengaruh nyata terhadap waktu meleleh es krim. Kecepatan meleleh adalah waktu yang dibutuhkan es krim untuk meleleh sempurna pada suhu ruang setelah pembekuan dalam freezer. Es krim diharapkan tidak cepat meleleh pada suhu ruang namun cepat meleleh pada suhu tubuh (Hubeis, 1995). Penambahan prosentase susu full cream dalam bahan es krim akan meningkatkan fraksi kandungan lemak dalam bahan, sehingga mempercepat waktu meleleh dari es krim sari kacang hijau. Lemak susu berfungsi untuk menghasilkan karakteristik tekstur yang lembut, membantu memberikan bentuk dan kepadatan serta memeberikan sifat meleleh yang baik (Padaga et al., 2005).

\section{Organoleptik Rasa}

Rasa merupakan sensasi yang terbentuk dari hasil perpaduan bahan dan komposisinya pada suatu produk makanan oleh indra pengecap. Suatu produk dapat diterima oleh konsumen apabila memiliki rasa yang sesuai dengan yang diinginkan (Kartika, dkk, 1988). Penambahan prosentase susu full cream pada pembuatan es krim sari kacang hijau tidak berpengaruh nyata terhadap organolepstik rasa. Rasa pedas jahe pada es krim sari kacang hijau dapat dinetralkan dengan penambahan susu full cream yang memberikan rasa yang netral. Secara penilaian hedonik penambahan susu full cream meningkatkan kesukaan panelis.

\section{KESIMPULAN}

Proporsi penambahan ekstrak jahe pada es krim sari kacang hijau memberikan pengaruh tidak berbeda nyata $(\mathrm{p}<0.05)$ terhadap kadar protein, dan berbeda nyata terhadap parameter yang lain yaitu Overrun, Waktu Leleh, serta nilai oganoleptik rasa. Prosentase penambahan Susu full Cream pada es krim sari kacang hijau memberikan pengaruh nyata terhadap kandungan protein, Overrun, Waktu leleh, dan nilai organoleptik es krim sari kacang hijau. Perlakuan terbaiknya diperoleh pada kombinasi perlakuan J2S4 yaitu penambahan proporsi ekstrak jahe terhadap sari kacang hijau 20:80\% dan Prosentase penambahan susu full cream $20 \%$, dimana kadar protein, kualitas overrun dan Waktu leleh sudah memenuhi standar mutu es krim skala rumah tangga. Kemudian berdasarkan nilai organoleptik rasa sudah memenuhi tingkat kesukaan. 


\section{SARAN}

Pemanfaatan rempah-rempah dan biji-bijian yang kaya akan protein dan serat berpotensi sebagai bahan pembuatan es krim dan perlu dilakukan penelitian lebih lanjut.

\section{DAFTAR PUSTAKA}

Amrina, rosyana. 2013. pembuatan es krim kacang hijau dengan susu kedelai sebagai makanan rendah lemak menggunakan ice cream maker. Skripsi.Teknik kimia. Universitas Diponegoro. Semarang.

Filiyanti, I., D. R. Affandi, dan B. S. Amanto. 2013. Kajian penggunaan susu tempe dan ubi jalar ungu sebagai pengganti susu skim pada pembuatan es krim nabati berbahan dasar santan kelapa. Jurnal Tekno sains Pangan Vol 2 (2):2302-0733.
Guner, A. M. Ardic, A. Keles and Y. Dogruer. 2007. Production of yogurt ice cream at different acidity. International J. Food Sci. and Tech. 42: 948-952

Hubeis M., 1995, Paket Industri Pangan Es Krim Ekonomi Skala IndustriKecil, Bulletin Fakultas Teknologi Industri Pangan, Institut Pertanian Bogor, Vol. VII (I), Hal 100-102.

Kartika, B., Hastuti, P dan Supartono, W. 1988. Pedoman Uji Inderawi Bahan Pangan. PAU Pangan dan Gizi-UGM, Yogyakarta.

Muse M.R. and Hartel, R.W., 2004, Ice Cream Structural Elements That Affect Melting Rate and Hardness American Dairy Science Association. Jurnal of dairy science $87: 1$ 10.

Padaga M dan Manik E. Sawitri, 2005, Es Krim Yang Sehat, Trubus Agrisarana, Surabaya. 